\section{Sevillian transport jars in early colonial America: the case of Santa María La Antigua del Darién (Colombia)}

\author{
Samantha Gomez Ferrer, ${ }^{1}$ \\ Jaume Buxeda i Garrigós, ${ }^{1}$ \\ Javier G. Iñañez, 2,3 \\ Fernando de Amores Carredano, ${ }^{4}$ \\ Adriana Alzate Gallego' \\ 'Department of Prehistory, Ancient \\ History and Archeology, Faculty of \\ Geography and History, University of \\ Barcelona; 'Department of Geography, \\ Prehistory and Archeology, University \\ of País Vasco/Vitoria-Gasteiz; \\ ${ }^{3}$ Basque Foundation for Science, Bilbao; \\ ${ }^{4}$ Department of Prehistory and \\ Archeology, University of Sevilla, Spain
}

\section{Abstract}

Within the scope of the TECNOLONIAL (HAR2008-02834/HIST) project, an archaeological and archaeometric research is being conducted in order to clarify and systematize transport jars production in the Iberian peninsula and their distribution abroad, especially to the Americas, from the $15^{\text {th }}$ to the $17^{\text {th }}$ century. The production centre of Seville, in the Crown of Castile, produced large glazed and unglazed transport jars, called botijas, which were mainly devoted to the Atlantic trade network. The present study accounts for the first results obtained from an initial sample of 34 transport jars dated around the $15^{\text {th }}-16^{\text {th }}$ centuries from the production centre of Seville and the reception site of Santa María de la Antigua del Darién (gulf of Urabá, Colombia). This latter site is especially significant since it was the first Spanish foundation (1510) in continental America that obtained the title of town, and was the seat for the Governor of the new region called Castilla de Oro, as well as for the first diocese. All individuals were analyzed by means of $\mathrm{x}$-ray fluorescence and diffraction analyses and then compared with the majolica production database from Seville. The results enabled us to define the first reference groups for such modern transport jars, and to get a first insight into the jars coming to the Americas in the early $16^{\text {th }}$ century whose provenance can be linked to Seville, but not Triana.

\section{Introduction}

The emergence of the new colonial world broke with the traditional coastal trade scheme established in the Mediterranean sea and added a new practice in the transport of goods. The new long-distance trade requirements gave rise to the creation of a new type of transport and storage jar. Seville developed the production of botijas, or olive jars (Goggin, 1960), i.e. large glazed or unglazed transport jars devoted to the transatlantic trade network (Amores Carredano and Chisvert Jiménez, 1993).

During the $15^{\text {th }}$ and $16^{\text {th }}$ centuries, i.e. after the Spanish colonized the Americas, the Spanish town of Seville evolved into a largescale pottery producing centre for the new colonial world and underwent a large urban development. The increased importance of Seville was mainly due to the fact that this city's inland fluvial port served as both the departure point and the final destination for most Spanish galleons trading with the Americas in the so called Carrera de Indias. In order to supervise the traffic of goods, a bureau of trade called Casa de la Contratación was established in 1503. Its primary office was in Seville and lasted for more than 200 years (1503-1717). Such organization and control of goods caused an exceptional industrial intensification. As a consequence, pottery workshops moved outside the city, in the Triana area, due to public health issues, as reported by documentary and archaeological evidences. Pottery workshops were relocated in Triana area probably around the late $15^{\text {th }}$ or early $16^{\text {th }}$ century, even if the area flourished after the mid-16 ${ }^{\text {th }}$ century (Sánchez Cortegana, 1994).

Prior to this change the Morisco ware existed (Lister and Lister, 1976; Lister and Lister, 1982), and included the so-called cuerda seca technique. This ware featured an outline drawing made by a mixture of manganese oxide with animal fat and glazed pigment. The spaces in between were either totally or partly filled with coloured glazes (Pérez-Arantegui $e t$ al., 1999). Cuerda-seca technique may date back to the $10^{\text {th }}$ century $\mathrm{BC}$, at the time of the islamic caliphate of Cordoba (South-Iberian peninsula), and was adopted all throughout the Middle Age, with its highest expansion in the $12^{\text {th }}$ and $13^{\text {th }}$ centuries. After the Christian conquered the islamic kingdoms of the Iberian peninsula, the technique was confined to mudejar craftsmen (i.e. craftsmen of Moorish origin), until it gradually disappeared in the middle of the $16^{\text {th }}$ century (Sánchez Cortegana, 1994). Unfortunately, the archaeological records of the cuerda seca production are scarce. Arguably, the few craftsmen who produced cuerda seca were of Islamic origin, as testified by the possible concentration of workshops in the area of San Pedro also called adarvejo de los moros (i.e. Moorish walls) (Sánchez Cortegana, 1994; Lister and Lister, 1982). Though the extent of findings is still limited, the archaeological records of Triana
Correspondence: Samantha Gomez Ferrer, Department of Prehistory, Ancient History and Archeology, Faculty of Geography and History, University of Barcelona, C/Montalegre 6, 08001 Barcelona, Spain.

Tel. +34.934.037.529 - Fax: +34.934.037.541.

E-mail: sgomezferrer@ub.edu

Key words: transport jars, provenance, colonial america, $\mathrm{x}$-ray fluorescence, $\mathrm{x}$-ray diffraction.

Citation: Gomez Ferrer S, Buxeda i Garrigós J, Garcia Iñañez J, de Amores Carredano F, Alzate Gallego A, 2013. Sevillian transport jars in early colonial America: the case of Santa María La Antigua del Darién (Colombia). In: RH Tykot (ed.) Proceedings of the 38th International Symposium on Archeometry - May 10th-14th 2010, Tampa, Florida. Open Journal of Archaeometry $1: e 3$.

Acknowledgments: the present paper is part of the research project TECNOLONIAL (HAR200802834/HIST) funded by the Ministerio de Economía y Competitividad (Spain). Samantha Gomez Ferrer is indebted to the support of the FPI program (BES-2009-012418) by the Ministerio de Economía y Competitividad (Spain). Javier G. Iñañez is indebted to the support of the Marie Curie International Outgoing Fellowship for Career Development Program of the European Community (ARCHSYMB PIOF-GA-2008-221399). The analyses have been performed at the Centres Científics $i$ Tecnològics, University of Barcelona (Spain).

Contributions: the authors contributed equally.

Conflict of interests: the authors declare no potential conflict of interests.

Presented at the $38^{\text {th }}$ International Symposium on Archaeometry - May $10^{\text {th }}-14^{\text {th }} 2010$, Tampa, Florida.

This work is licensed under a Creative Commons Attribution 3.0 License (by-nc 3.0).

(C) Copyright S.G. Ferrer et al., 2013

Licensee PAGEPress, Italy

Open Journal of Archaeometry 2013; 1:e3

doi:10.4081/arc.2013.e3

workshops seemingly report a possible production of cuerda seca in this area. As far as the expansion to the Americas is concerned, written documentation suggests that pottery sent to America in the first two decades of the $16^{\text {th }}$ century was characterized by a broad typology, despite the limited number of goods shipped. Europeans brought from Europe all types of pottery that they needed (Sánchez Cortegana, 1996). In this process, a first milestone was the foundation of Santa María la Antigua del Darién (SMAD), one of the first European settlements on continental America (Figure 1). In 1510, Vasco Núñez de Balboa and Martín 
Fernández de Enciso founded SMAD after several failed trials, like Santa Cruz (Venezuela) or San Sebastián de Urabá (Colombia). In 1513, the Castilian Crown gave the title of town to SMAD, the first town on continental America, and in 1514 the governor Pedrarias Dávila arrived with a contingent of 2000 people formed by soldiers, artisans, doctors, women, and the first bishop, Fray Juan de Quevedo. The expedition of 1514 was a major change in the first years of the American colonization, since it was the first time that the Crown of Castile organized and paid with public funds a whole movement of people in order to start an urban settlement. The ultimate goal of the Crown of Castile was to give birth to other new villages and start a nucleus of Castilian population in continental America. However, after several problems and political tensions, life in SMAD proved to be impossible. Thus, in 1519 the Governor founded the town of Panamá, where most people moved in 1520 (Alzate Gallego, 2006). Most importantly, large documentary evidence exists with regard to 1514's expeditions and informs us about the origin of supply goods. Food and several types of pottery are said to be of Sevillian origin (Mena García, 1998), an origin that seems also plausible for the ceramic transport jars of these food supplies. Since the abandonment of the old city of SMAD, its actual location was unknown until 1957, when the site was eventually identified by archaeologists. However, the only excavation was a limited program conducted in the 1960s and 1970s by Graciliano Arcila Vélez, who made a small plan and several archaeological surveys that revealed the only archaeological remains available nowadays (Alzate Gallego, 2006). Recently, the Universidad Nacional de Colombia started a new archaeological project on the site, unearthing an important set of ceramics from the period under consideration (Alzate Gallego, 2000).

Thus, the objective of this paper was to archaeometrically characterize transport jars recovered at SMAD in order to shed light on the characteristics of such vases from Seville, much less studied than other types of pottery produced there (like majolica). Moreover, it is also important that such transport jars are dated back to the 1513-1520 period, an early period in Seville pottery production, before the major role played by Triana, whose products have been largely characterized in contrast to other production areas of this centre.

\section{Materials and Methods}

In order to shed light on the first Sevillian transport jars coming to the Americas, 34 transport jars were analyzed in this study. Twenty-three were unearthed from the site of
SMAD (COL001 to COL023), while 11 others were transport jars from Seville (SEV001 to SEV010, recovered at Seville itself; and BCN138, unearthed at Barcelona) (Figure 2). These results were compared with the ARQUB archaeometric data bank for the production centre of Seville (labelled as MJ or TRI, unearthed at Seville, as well as from sites in the Canary islands), currently comprising 105 individuals (87 majolica individuals dated back to the $16^{\text {th }}$ and $17^{\text {th }}$ century; 14 green or honey coarse glazed pottery from the $13^{\text {th }}$ and $14^{\text {th }}$ century; and 4 cuerda seca individuals dated back to the end of the $15^{\text {th }}$ and beginning of the $16^{\text {th }}$ century) (Iñañez, 2007).

All individuals were chemically analyzed by
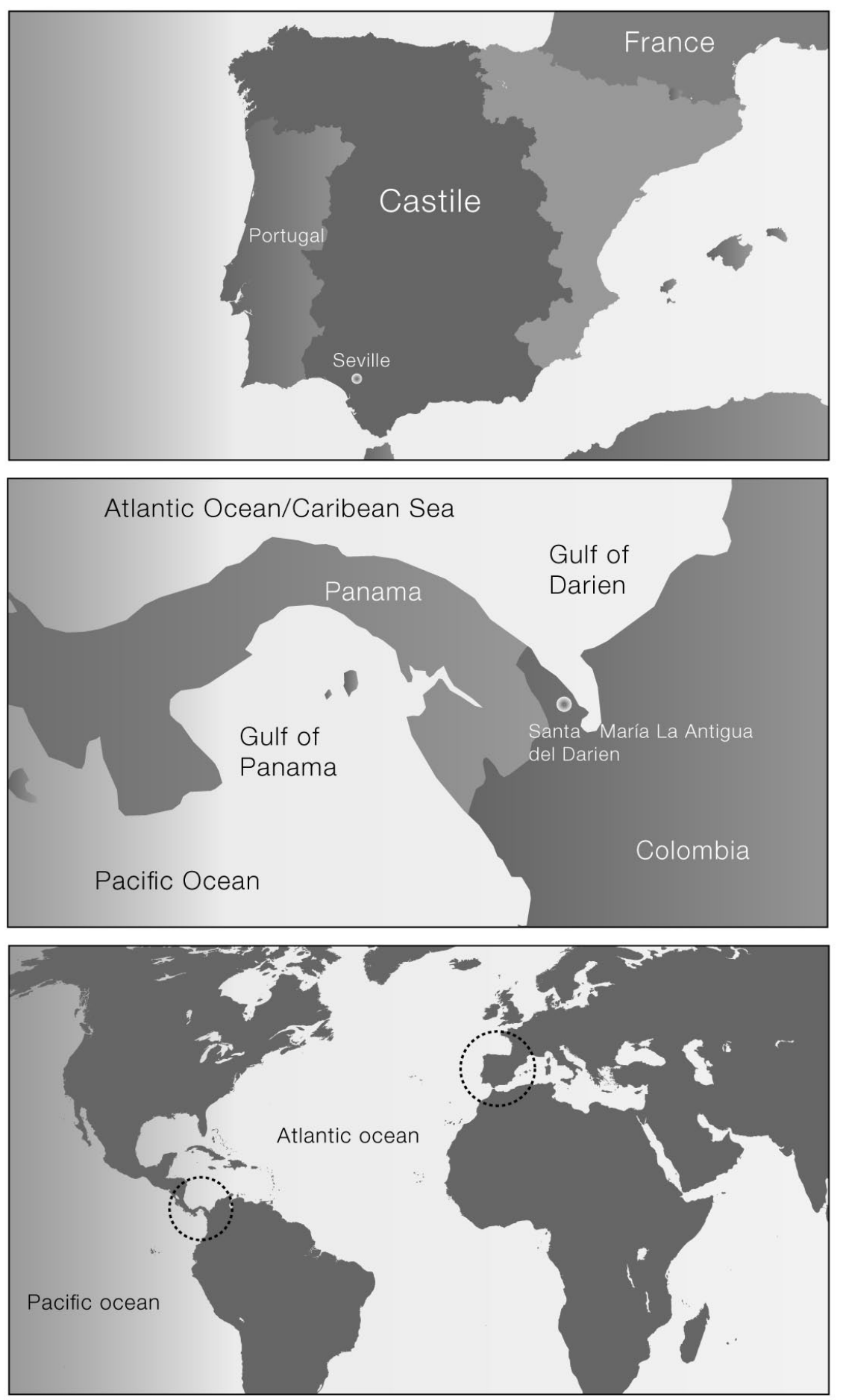

Figure 1. Geographical map of the Crown of Castile with Seville (upper panel), Gulf of Urabá with Santa Maria de la Antigua del Darién (central panel), and the Atlantic Ocean (lower panel). 
means of x-ray fluorescence (XRF). First, all superficial layers of the potsherds were mechanically removed. Then, the samples were powdered and homogenized in a tungsten carbide mill Spex Mixer model 8000 (SPEX SamplePrep, Metuchen, NJ, USA). The chemical composition was determined from the powder previously dried in oven for $12 \mathrm{~h}$ at $105^{\circ} \mathrm{C}$. Major and minor elements were determined by preparing duplicates of glass beads and were expressed as oxides (wt\%). Each 30$\mathrm{mm}$ glass bead was prepared using $0.3 \mathrm{~g}$ of the dried powdered sample mixed up with $5.7 \mathrm{~g}$ of lithium tetraborate $\left(\mathrm{Li}_{2} \mathrm{~B}_{4} \mathrm{O}_{7}\right)$. Subsequently, 5 $\mathrm{mg}$ of lithium iodide (LiI) was added in order to control the surface tension of the glass bead. This homogenized mixture was deposited on a Pt-Au crucible (95:5) and melted in a fullyautomatic bead preparation system PANalytical Perl'X-3 (PANalytical, Almelo, The Netherlands) at a temperature of $1125^{\circ} \mathrm{C}$. Trace elements were determined by powdered pills made from $5 \mathrm{~g}$ of the powdered specimen mixed with $2 \mathrm{~mL}$ of a n-butylmethacrylate synthetic resin solution (Elvacite ${ }^{\circledR}$ 2044, in 20\% acetone). This mixture, manually homogenized in an agate mortar to dryness and placed on a base of boric acid $\left(\mathrm{H}_{3} \mathrm{BO}_{3}\right)$ in a $40-\mathrm{mm}$ diameter aluminium vessel, was subjected to a pressure of $200 \mathrm{kN}$ for $60 \mathrm{~s}$ in a Herzog press (HERZOG Automation Corp., Cleveland, OH, USA). The quantification of the concentrations was performed using an Axios ${ }^{\mathrm{mAX}}$-Advanced PANalytical spectrometer (PANalytical) with an Rh excitation source using a calibration line performed with 56 International Geological Standards. Interferences were taken into consideration and matrix effects were corrected by using the PANanalytical ProTrace software for trace elements (PANalytical). The elements determined comprised $\mathrm{Fe}_{2} \mathrm{O}_{3}$ (as total $\mathrm{Fe}$ ), $\mathrm{Al}_{2} \mathrm{O}_{3}, \mathrm{MnO}, \mathrm{P}_{2} \mathrm{O}_{5}$, $\mathrm{TiO}_{2}, \mathrm{MgO}, \mathrm{CaO}, \mathrm{Na}_{2} \mathrm{O}, \mathrm{K}_{2} \mathrm{O}, \mathrm{SiO}_{2}, \mathrm{Ba}, \mathrm{Rb}, \mathrm{Mo}$, Th, Nb, Pb, Zr, Y, Sr, Sn, Ce, Co, Ga, V, Zn, W, $\mathrm{Cu}, \mathrm{Ni}$, and $\mathrm{Cr}$. Loss of ignition (LOI) was determined by firing $0.3 \mathrm{~g}$ of dried specimen at $950^{\circ} \mathrm{C}$ for $3 \mathrm{~h}$. Calcinations were carried out in a Heraeus muffle model M-110, by using a heating rate of $3.4^{\circ} \mathrm{C} \mathrm{min}{ }^{-1}$ and free cooling. Thus, the sum of major, minor, trace elements concentrations and LOI, is located within a range of $98-102 \%$. A detailed description of the method adopted, as well as its precision and accuracy, has already been published (Hein $e t$ al., 2002).

Mineralogical characterization of all individuals was performed by $\mathrm{x}$-ray diffraction (XRD). Measurements were made using a Bragg-Brentano geometry PANalytical X'Pert PRO MPD Alpha-l diffractometer (radium=240 $\mathrm{mm}$ ) (PANalytical) working with the $\mathrm{Cu}-\mathrm{Ka}$ radiation (l=1.5406 ̊) (45 kV, $40 \mathrm{~mA})$ equipped with an X'celerator detector. Measurements where taken from 4 to $100^{\circ} 2$ with a measure step of $0.017^{\circ} 2$ and an acquisition time of $50 \mathrm{~s}$ per step. Evaluations of the crystalline phases present in each analyzed individual were performed with the software package Siemens DIFFRACT/AT (Siemens, Munich, Germany) including the database of the ICDD-JCPDS 2006 (The International Centre for Diffraction Data, Newtown Square, PA, USA).

\section{Results and Discussion}

In statistical terms, the elemental concentrations determined by means of XRF are a special case of the projective $\mathrm{d}+1$-dimensional space, the simplex $S^{d}$. Projective points are represented by a $\mathrm{d}+1$-dimensional vector of coordinates adding up to a constant $k\left(k \hat{\mathrm{I}} R^{+}\right)$:

$\mathrm{x}=\left[\mathrm{x}_{1}, \ldots, \mathrm{x}_{d+1}\right] \mid \mathrm{x}_{\mathrm{i}} \geq 0(\mathrm{i}=1, \ldots, \mathrm{d}+1)$,

$\mathrm{x}_{1}+\ldots+\mathrm{x}_{d+1}=k$

(in the present case, $\mathrm{k}=100$ ), a subset in the positive orthant, following a multiplicative model with a logarithmic interval metrics (Barceló-Vidal et al., 2001; Aitchison, 2005; Buxeda i Garrigós, 2008). Therefore, for the statistical data treatment, raw concentrations have been centered log ratio (CLR) transformed, according to this formula:

$$
\mid \mathbf{x} \in \mathrm{S}^{d} \rightarrow \mathbf{z}=\log \left(\frac{\mathbf{x}}{g(\mathbf{x})}\right) \in \mathbf{R}^{D}
$$

where $S^{d}$ is the d-dimensional simplex, and $\mathrm{g}(\mathrm{x})$ the geometric mean of all $\mathrm{D}(\mathrm{D}=\mathrm{d}+1)$ components of x (Buxeda i Garrigós, 1999; Aitchison, 1986).

Some elements were not considered for the chemical study. Among those determined by XRF, Co and W were not used because of the contamination provided by the tungsten carbide cell where samples were powdered. Mo presents a concentration always below the lower detection limit and cannot accurately be determined. $\mathrm{Pb}$ and $\mathrm{Sn}$ are usually present in high amounts due to the glaze of some samples; for instance, $\mathrm{Pb}$ content largely exceeds the upper XRF regression limit (928 ppm). Therefore, these high $\mathrm{Pb}$ amounts result in interferences for trace elements such as $\mathrm{Ga}, \mathrm{Y}$, $\mathrm{Th}$ and $\mathrm{Rb}$, which cannot be corrected. $\mathrm{P}_{2} \mathrm{O}_{5}$ was not considered due to potential contaminations during burial. Lastly, a double alteration and contamination process has been detected in an important number of samples. This process reports the leaching of $K$ and, sometimes, $\mathrm{Rb}$, from the matrix, with a subsequent enrichment of $\mathrm{Na}$ because of analcime crystallization (Buxeda i Garrigós et al., 2002; Schwedt et al., 2006; Zacharias et al., 2007). Therefore, these alteration and contamination processes affect the components in the matrix composition, without any possibility of satisfactory correction. As a result, $\mathrm{Na}, \mathrm{K}$, and $\mathrm{Rb}$ were also sometimes removed from consideration during statistical analysis.

The statistical treatment of the XRF data is summarized by the cluster analysis in Figure 3 . The study of the cluster suggests the existence of several different groups. On the left

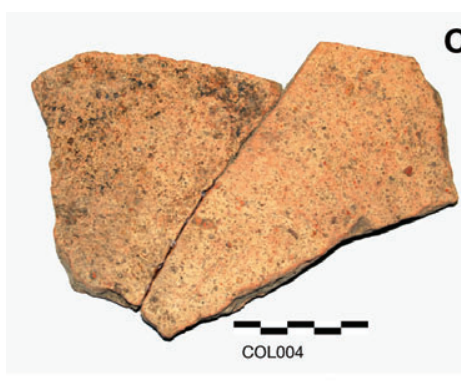

CL
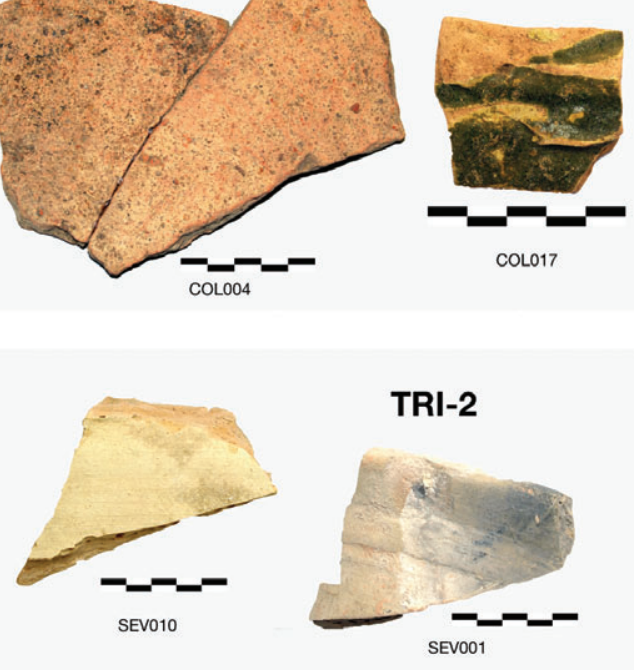

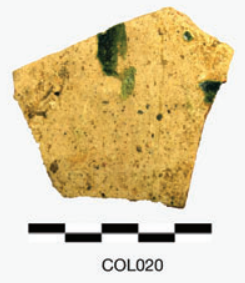

$\mathbf{X 1}$

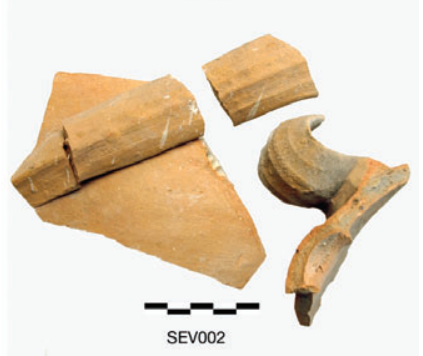

Figure 2. Macrophotographs of some representative individuals according to the defined groups (see the text). CL COL004 and COL017; X1: COL020 and SEV002; TRI-2: SEV001 and SEV010. 


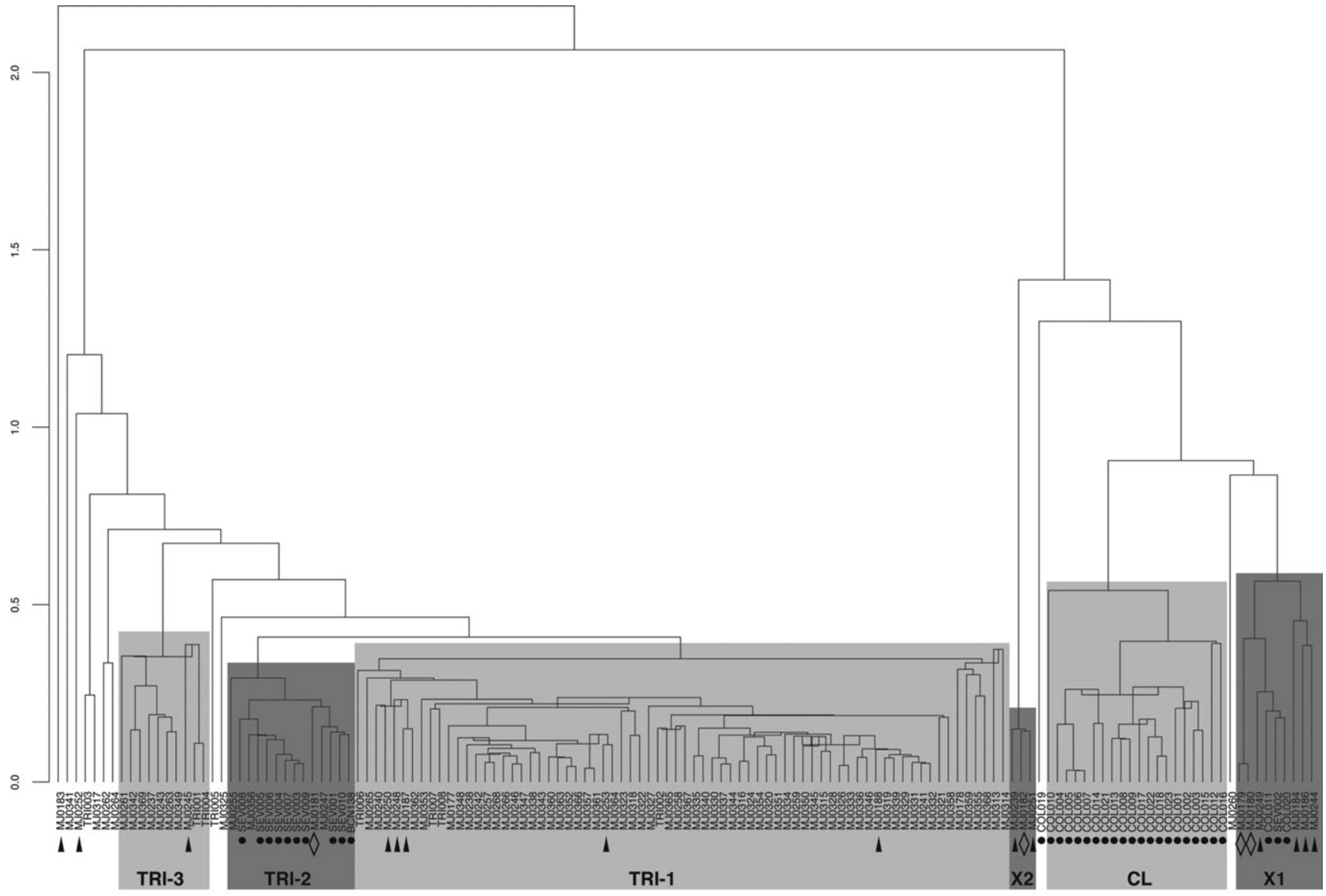

Figure 3. Dendrogram resulting from cluster analysis using squared Euclidean distance and centroid agglomerative method on the subcomposition $\mathrm{Fe}_{2} \mathrm{O}_{3}, \mathrm{Al}_{2} \mathrm{O}_{3}, \mathrm{MnO}$, $\mathrm{TiO}_{2}, \mathrm{MgO}, \mathrm{CaO}, \mathrm{Na}_{2} \mathrm{O}, \mathrm{K}_{2} \mathrm{O}, \mathrm{SiO}_{2}, \mathrm{Ba}, \mathrm{Nb}, \mathrm{Zr}, \mathrm{Sr}, \mathrm{Ce}, \mathrm{V}, \mathrm{Zn}, \mathrm{Ni}$, and Cr, CLR transformed. Black circles represent transport jars, black triangles indicate coarse glazed pottery, white diamonds stand for cuerda seca, and no symbol is majolica.

Table 1. Elements concentration (mean and standard deviation on normalised data) for each chemical group.

\begin{tabular}{|c|c|c|c|c|c|c|c|c|c|c|c|c|c|}
\hline \multirow{3}{*}{ Element } & \multicolumn{12}{|c|}{ Chemical group } & \multirow{3}{*}{ COL019 } \\
\hline & \multicolumn{2}{|c|}{$\begin{array}{c}\text { TRI1 } \\
(\mathrm{n}=72)\end{array}$} & \multicolumn{2}{|c|}{$\begin{array}{c}\text { TRI2 } \\
(\mathrm{n}=15)\end{array}$} & \multicolumn{2}{|c|}{$\begin{array}{c}\text { TRI3 } \\
(\mathrm{n}=10)\end{array}$} & \multicolumn{2}{|c|}{$\begin{array}{c}X 1 \\
(n=9)\end{array}$} & \multicolumn{2}{|c|}{$\begin{array}{c}\mathrm{X} 2 \\
(\mathrm{n}=3)\end{array}$} & \multicolumn{2}{|c|}{$\begin{array}{c}C L \\
(n=20)\end{array}$} & \\
\hline & $\mathrm{m}$ & sd & m & sd & m & sd & m & sd & m & sd & $\mathrm{m}$ & sd & \\
\hline $\mathrm{Fe}_{2} \mathrm{O}_{3}(\%)$ & 4.86 & 0.31 & 5.74 & 0.26 & 5.09 & 0.26 & 6.22 & 0.78 & 6.30 & 0.20 & 7.35 & 0.41 & 6.84 \\
\hline $\mathrm{Al}_{2} \mathrm{O}_{3}(\%)$ & 12.68 & 0.86 & 14.68 & 0.63 & 13.22 & 0.71 & 15.52 & 1.56 & 15.34 & 0.49 & 18.52 & 0.51 & 17.05 \\
\hline $\mathrm{MnO}(\%)$ & 0.08 & 0.01 & 0.10 & 0.01 & 0.09 & 0.01 & 0.09 & 0.01 & 0.11 & 0.01 & 0.11 & 0.02 & 0.10 \\
\hline $\mathrm{TiO}_{2}(\%)$ & 0.67 & 0.04 & 0.68 & 0.05 & 0.68 & 0.03 & 0.74 & 0.06 & 0.92 & 0.08 & 0.83 & 0.04 & 0.90 \\
\hline $\mathrm{MgO}(\%)$ & 3.18 & 0.29 & 3.34 & 0.31 & 3.62 & 0.32 & 3.39 & 0.73 & 2.07 & 0.20 & 3.07 & 0.31 & 2.98 \\
\hline $\mathrm{CaO}(\%)$ & 22.03 & 2.47 & 18.70 & 1.69 & 21.56 & 2.04 & 12.40 & 1.40 & 8.69 & 0.59 & 7.70 & 1.18 & 5.78 \\
\hline $\mathrm{Na}_{2} \mathrm{O}(\%)$ & 0.96 & 0.20 & 0.76 & 0.09 & 1.48 & 0.15 & 0.71 & 0.16 & 1.29 & 0.13 & 0.47 & 0.06 & 0.29 \\
\hline K2O (\%) & 2.08 & 0.46 & 2.87 & 0.20 & 1.23 & 0.31 & 2.96 & 0.26 & 2.40 & 0.20 & 2.84 & 0.30 & 2.08 \\
\hline SiO2 (\%) & 53.33 & 2.03 & 53.00 & 2.25 & 52.91 & 1.87 & 57.85 & 2.74 & 62.76 & 1.55 & 58.95 & 1.65 & 63.84 \\
\hline $\mathrm{Ba}(\mathrm{ppm})$ & 344 & 38 & 399 & 26 & 333 & 45 & 387 & 53 & 356 & 25 & 594 & 122 & 445 \\
\hline $\mathrm{Nb}$ (ppm) & 17 & 1 & 18 & 1 & 17 & 1 & 18 & 1 & 18 & 2 & 20 & 1 & 22 \\
\hline $\mathrm{Zr}(\mathrm{ppm})$ & 196 & 20 & 161 & 24 & 200 & 28 & 169 & 17 & 234 & 35 & 175 & 18 & 267 \\
\hline Sr (ppm) & 431 & 57 & 408 & 32 & 482 & 31 & 325 & 43 & 251 & 31 & 260 & 52 & 153 \\
\hline Ce (ppm) & 53 & 8 & 55 & 11 & 49 & 10 & 58 & 16 & 57 & 5 & 76 & 9 & 77 \\
\hline $\mathrm{V}(\mathrm{ppm})$ & 70 & 8 & 84 & 7 & 83 & 11 & 100 & 12 & 98 & 4 & 112 & 15 & 82 \\
\hline Zn (ppm) & 86 & 9 & 91 & 6 & 91 & 6 & 94 & 7 & 83 & 7 & 118 & 18 & 131 \\
\hline $\mathrm{Ni}$ (ppm) & 33 & 5 & 40 & 3 & 41 & 3 & 42 & 5 & 36 & 4 & 48 & 3 & 41 \\
\hline $\mathrm{Cr}(\mathrm{ppm})$ & 78 & 9 & 70 & 9 & 82 & 9 & 95 & 7 & 98 & 2 & 101 & 6 & 104 \\
\hline
\end{tabular}

$\mathrm{n}$, number of individuals; $\mathrm{m}$, mean; sd, standard deviation; ppm, parts per million $\left(\mu \mathrm{g} \cdot \mathrm{g}^{-1}\right)$. 
side, a broad heterogeneous trend has been highlighted over a grey pattern. This heterogeneous trend can be identified with the most typical Sevillian productions, which are also the most studied ones. Several groups are easily recognized. On the one hand, the TRI-1 group is almost exclusively composed by majolica, even if five coarse glazed individuals are also included. Pottery in this group came mostly from archaeological excavations in Seville city, especially in the workshops of Valladares, Pureza and Plaza de Armas, all three located in Triana. It must be stressed that the three characterized workshops are dated back to 1550 onwards, several decades after the foundation and fall of SMAD. The TRI3 group is closely related to the TRI- 1 group. It is also composed almost exclusively by majolica including some individuals from the three Triana workshops, except for one coarse glaze individual. The main difference between the TRI-1 and TRI-3 groups is related to relative $\mathrm{Na}_{2} \mathrm{O}$ and $\mathrm{K}_{2} \mathrm{O}$ concentrations. Nevertheless, both groups show the highest relative $\mathrm{CaO}$ content in the dataset (Table 1). On the other hand, the TRI-2 group is composed mainly by transport jars, even if it also includes one cuerda seca and three majolica individuals, one of them belonging to the Plaza de Armas workshop. Regarding the transport jars in this group, all of them come from the filled vaults of the Seville's Cathedral; specifically, from Cámara Alta, built in 1514, and from San Isidoro, built in 1520 , therefore contemporary to SMAD. In Seville, the use of recycled ceramics as materials for constructions of different buildings was quite frequent because they were relatively light and bulky items (Sánchez Cortegana, 1994; Pleguezuelo Hernández et al., 1999). This TRI-2 group shows lower relative concentrations of $\mathrm{CaO}$ and $\mathrm{Na}_{2} \mathrm{O}$, as well as higher relative concentrations of $\mathrm{K}_{2} \mathrm{O}, \mathrm{Fe}_{2} \mathrm{O}_{3}$, $\mathrm{Al}_{2} \mathrm{O}_{3}$, and $\mathrm{Ba}$. It seems possible that this group is also related to Triana area, with slight compositional differences, possibly due to the type of pottery produced or to small variations in the exploited clay beds, or even to chronological differences. In any case, the presence of one majolica individual from Plaza de Armas points out that the chemical composition in groups TRI-1, TRI-3, and TRI-2 are not necessarily clear-cut. Therefore, this heterogeneous trend must be, at present, related to pottery production in Triana area.

Furthermore, the three different groups can also be clearly identified in the dendrogram (Figure 3), together with two individuals (one majolica and one transport jar unearthed at SMAD) remaining as outliers. In general, these groups and individuals exhibit lower relative $\mathrm{CaO}$ values, as well as higher relative $\mathrm{Fe}_{2} \mathrm{O}_{3}$ and $\mathrm{Al}_{2} \mathrm{O}_{3}$ (Table 1), and they correspond to non-majolica pottery, except for one. In addition, there is a higher content of $\mathrm{SiO}_{2}$. The $\mathrm{X} 1$ group is formed by 9 individuals from different backgrounds and types including transport jars from the Cathedral and SMAD, coarse glazed pottery from Gran Canaria and Seville, and cuerda seca from Seville. Interestingly, there is no majolica in this group, only utilitarian ceramics. The transport jar from Seville is an olive jar dated back to early 1500 to 1580 , according to Goggin (1960). Amores Carredano and Chisvert Jiménez (1993) indentified these forms as the first jars of transatlantic trade, being an adaptation of traditional cantimploras. It is relevant that this individual is from the same archaeological context as the other transport jars from Seville, from the filled vaults of the Capilla de San Isidoro. This scenario may lead to the interpretation that X1 must be from a Sevillian provenance not yet determined. Besides, the coarse glazed pottery from Gran Canaria was recovered in two sites that can be dated back to the end of the $15^{\text {th }}$ century onwards. There are no good chronological indicators for the two coarse glazed pottery individuals recovered at Seville itself. Therefore, it seems that this X1 group can be dated back to the early production of Seville (end of the $15^{\text {th }}$ century-beginning of the $16^{\text {th }}$ century). Three other individuals two coarse glazed individuals from Gran Canaria and one cuerda seca - are grouped together in the $\mathrm{X} 2$ group. This group also contains non-majolica pottery and is dated back to the early Sevillian production. From a chemical point of view, it seems to be related to the previous X1 group (Table 1), though differences can be seen in higher relative $\mathrm{SiO}_{2}$ and $\mathrm{Zr}$ concentrations contrasting with lower relative $\mathrm{CaO}, \mathrm{Ba}$, and $\mathrm{Sr}$ concentrations. Moreover, $\mathrm{X} 2$ also exhibits higher $\mathrm{Na}_{2} \mathrm{O}$ and lower $\mathrm{K}_{2} \mathrm{O}$ relative concentrations. Finally, the CL group includes 20 transport jars from SMAD. This group has the lowest relative $\mathrm{CaO}$ and $\mathrm{Na}_{2} \mathrm{O}$ concentrations, but the highest relative $\mathrm{Fe}_{2} \mathrm{O}_{3}$ and $\mathrm{Ba}$ concentrations (Table 1). This situation made the paste of CL pottery reddish, while lower $\mathrm{Fe}_{2} \mathrm{O}_{3}$ and higher $\mathrm{CaO}$ amounts of the majolica pottery from Seville provided a light buff colour to their paste due to the incorporation of iron oxides into calcium iron silicates (Molera et al., 1998).

Finally, the study of the transport jars by

Table 2. Estimated equivalent firing temperature according to the defined fabrics from the association of crystalline phases by $x$-ray diffraction.

\begin{tabular}{|c|c|c|c|c|}
\hline \multirow{2}{*}{ Fabric $\left({ }^{\circ} \mathrm{C}\right)$} & \multirow[t]{2}{*}{ Phases } & \multirow{2}{*}{$\begin{array}{c}\text { Groups } \\
\text { X1 }\end{array}$} & \multicolumn{2}{|c|}{ Total } \\
\hline & & & & \\
\hline F1 (850-900) & Afs, Cal, Di, Gh, Ilt, Hem, Pl, Qz & SEV002 & 1 & 3 \\
\hline F2 (900/950-1000) & Afs, Cal, Di, Gh, Ilt, ${ }^{*} \mathrm{Hem}, \mathrm{Pl}, \mathrm{Qz}$ & COL011 & 1 & \\
\hline \multirow[t]{2}{*}{ F3 (1000-1050) } & Afs, Cal, Di, Gh, Hem, Pl, Qz & COL020 & 1 & \\
\hline & \multicolumn{4}{|c|}{ CL } \\
\hline F1 (800/850-900) & Afs, Di, Ilt, Hem, Pl, Qz & COL002, 3, 4, 7, 9, 10, 13, 14, 15, 16, 17, 18, 21, 22, 23 & 15 & 20 \\
\hline F2 (900/950-1000) & Afs, Di, Ilt, * Hem, Pl, Qz & COL005 & 1 & \\
\hline \multirow[t]{2}{*}{ F3 (1000-1050) } & Afs, Di, Hem, Pl, Qz & COL001, 6, 8, 12 & 4 & \\
\hline & \multicolumn{4}{|c|}{ TRI-2 } \\
\hline F1 $(850-950)$ & Afs, Cal, Di, Gh, Ilt, Hem, Pl, Qz & SEV004, 5 & 2 & 10 \\
\hline F2 (950-1000) & Afs, Cal, Di, Gh, Ilt, ${ }^{*} \mathrm{Hem}, \mathrm{Pl}, \mathrm{Qz}$ & BCN138, SEV001, 9, 10 & 4 & \\
\hline F3 (1000-1050) & Afs, Cal, Di, Gh, Hem, Pl, Qz & SEV007, 8 & 2 & \\
\hline F4 (1000-1050 analcime) & Afs, Anl, Cal, Di, Gh, Hem, Pl, Qz & SEV003, 6 & 2 & \\
\hline
\end{tabular}


XRD enabled us to estimate the equivalent firing temperatures according to the fabrics defined by the association of crystalline phases [Table 2; abbreviations after Whitney and Evans (2010)]. Results show lower equivalent firing temperatures for transport jars belonging to groups X1 and CL, than those belonging to the possible Triana production in group TRI2. However, the still scarce set of transport jars characterized so far do not enable us to infer necessary technological differences in this respect.

\section{Conclusions}

The results of this study show the existence of at least two large ceramic industries in Seville, identified in different reference groups: the disappearing old mudejar tradition; and the vibrant majolica industry, which favoured the installation of Italian and Castilian artisans in Triana to produce majolica and other types of pottery, including transport jars. This situation notwithstanding, it is likely that more chemical groups are yet to be identified. In the case of transport jars, the results obtained so far have enabled us to identify a production most probably related with Triana area (group TRI-2). Besides, another group (X1) has also been identified, and its products are also present in SMAD, even if in a small proportion. Finally, another group accounts for more of the transport jars unearthed at SMAD (CL) with no definite analytical proof of Sevillian origin. However, this origin must still be kept as probable according to Pedrarias expedition's written sources and to background knowledge on the Castilian colonization of the Americas. Thus, the evidence studied so far enables us to hypothesize a complex structure of the Sevillian production, including a large number of reference groups which are, at present, unevenly known. Such groups might be related to the different areas of pottery production that were active during the city time history, exploiting different clay beds in different locations. Precisely, groups $\mathrm{X} 1, \mathrm{X} 2$, and $\mathrm{CL}$, seem to be related to the main activity of Seville (end of the $15^{\text {th }}$ centurybeginning of the $16^{\text {th }}$ century), before the flourishing of Triana area. In that respect, the transport jars recovered at SMAD are, at present, the largest set of such Sevillian early materials archaeometrically characterized. At the same time, they also are the main advice to be cautious when establishing provenances for a large production centre like Seville, whose complex structure may involve several reference groups not yet known. In this vein, the present results provide some of these new reference groups for such a complex production centre.

\section{References}

Aitchison J, 1986. The statistical analysis of compositional data. Chapman and Hall Ltd., London, UK.

Aitchison J, 2005. A concise guide to compositional data analysis. Universitat de Girona ed., Girona, Spain.

Alzate Gallego L, 2000. [Clasificando cerámica colonial en el Museo Universitario de la Universidad de Antioquia. Mayólicas del siglo XVI]. [Book in Spanish]. Universidad de Antioquía ed., Medellín, Colombia.

Alzate Gallego L, 2006. [Santa Maria de la Antigua del Darién: cerámica española con texto y de contexto en el Darién colombiano]. [Book in Spanish]. Universitat Autónoma de Barcelona ed., Barcelona, Spain.

Amores Carredano F, Chisvert Jiménez N, 1993. [Tipología de la cerámica bajomedieval y moderna sevillana (s. XV-XVIII): I, la loza quebrada de relleno de bóvedas]. [Article in Spanish]. SPAL: Revista de prehistoria y arqueología de la Universidad de Sevilla 2:269-328.

Barceló-Vidal C, Martin-Fernández J, Pawlowsky-Glahn V, 2001. Mathematical foundations of compositional data analysis. pp 1-20 in Proc. of IAMG'01-The annual meeting of the International Association for Mathematical Geology, 612 September 2001, Cancún, Mexico.

Buxeda i Garrigós J, 1999. Alteration and contamination of archaeological ceramics: the perturbation problem. J Archaeol Sci 26:295-313.

Buxeda i Garrigós J, Mommsen H, Tsolakidou A, 2002. Alterations of $\mathrm{Na}, \mathrm{K}$ and $\mathrm{Rb}$ concentrations in Mycenaean pottery and a proposed explanation using X-ray diffraction. Archaeometry 44:187-98.

Buxeda i Garrigós J, 2008. Revisiting the compositional data. Some fundamental questions and new prospects in Archaeometry and Archaeology. pp 1-18, in: J. Daunis-i-Estadella and J. MartínFernăndez (ed.), Proc. of CODAWORK'08 - The 3rd Compositional Data Analysis Workshop, May 27-30, Girona, Spain.

Goggin J, 1960. The Spanish olive jar; an introductory study. Yale University Publications in Anthropology, New Haven, CT, USA.

Hein A, Tsolakidou A, Iliopoulos I, Mommsen H, Buxeda i Garrigós J, Montana G, Kilikoglou V, 2002. Standardisation of elemental analytical techniques applied to provenance studies of archaeological ceramics: an inter laboratory calibration study. Analyst 127:542-53.

Iñañez J, 2007. [Caracterització arqueomètri- ca de la ceràmica vidriada decorada de la Baixa Edat Mitjana al Renaixement als centres productors de la Península Ibèrica, Tesis Doctorals en Xarxa]. [Thesis in Catalan]. Universitat de Barcelona ed., Barcelona, Spain.

Lister F, Lister RH, 1976. A descriptive dictionary for 500 years of Spanish-tradition ceramics: (13th through 18th centuries). Society for Historical Archaeology ed., Germantown, MD, USA.

Lister F, Lister RH, 1982. Sixteenth century maiolica pottery in the valley of Mexico. Anthropological papers of the University of Arizona, 39. University of Arizona ed., Tucson, AZ, USA.

Mena García C, 1998. [Sevilla y las flotas de Indias: la Gran Armada de Castilla del Oro, 1513-1514]. [Book in Spanish]. Universidad de Sevilla ed., Sevilla, Spain.

Molera J, Pradell T, Vendrell-Saz M, 1998. The colours of Ca-rich ceramic pastes: origin and characterization. Appl Clay Sci 13:187-202.

Pérez-Arantegui J, Soto M, Castillo JR, 1999. Examination of the "Cuerda Seca" Decoration Technique on Islamic Ceramics from al-Andalus (Spain). J Archaeol Sci 26:935-41.

Pleguezuelo Hernández A, Librero A, Espinosa M, Mora P, 1999. [Loza Quebrada procedente de la Capilla del Colegio-Universidad de Santa María de Jesús (Sevilla)]. [Article in Spanish]. SPAL: Revista de prehistoria y arqueología de la Universidad de Sevilla 8:26394.

Sánchez Cortegana JM, 1994. [El oficio de Ollero en Sevilla en el siglo XVI]. [Book in Spanish]. Diputación Provincial de Sevilla ed., Sevilla, Spain.

Sánchez Cortegana JM, 1996. [La cerámica exportada a América en el siglo XVI a través de la documentación del Archivo General de Indias: I. materiales arquitectónicos y contenedores de mercancías]. [Article in Spanish]. Laboratorio de Arte: Revista del Departamento de Historia del Arte 1:125-42.

Schwedt A, Mommsen H, Zacharias N, Buxeda i Garrigós J, 2006. Analcime crystallization and compositional profiles Comparing approaches to detect postdepositional alterations in archaeological pottery. Archaeometry 48:237-51.

Whitney DL, Evans BW, 2010. Abbreviations for names of rock-forming minerals. Am Mineral 95:185-7.

Zacharias N, Schwedt A, Buxeda i Garrigós J, Michael CT, Mommsen H, Kilikoglou V, 2007. A contribution to the study of postdepositional alterations of pottery using TL dating analysis. J Archaeol Sci 34:1804-9. 